\title{
WASH infrastructure and practices in primary health care clinics in the rural Vhembe District municipality in South Africa
}

\author{
N. Potgieter ${ }^{1 *}$ (D, N. T. Banda ${ }^{1}$, P. J. Becker ${ }^{2}$ and A. N. Traore-Hoffman ${ }^{1}$
}

\begin{abstract}
Background: South Africa has unique and diverse social and economic factors that have an impact on the provision of basic water, sanitation, hygiene and waste management infrastructure and practices at health care facilities in ensuring patient safety and prevent the spread of diseases.

Methods: The aim of this study was to evaluate water, sanitation and hygiene access and standards at 50 government owned public health care clinics in the rural region of the Vhembe district of South Africa during 2016/2017, using self-observation, an observation checklist, record reviews and interviews with clinic managers. Water quality from all available water sources on the clinic compound was analysed for Total coliform and E. coli counts using the Colilert Quanti-tray/2000 system. The prevalence of pathogenic diarrhea causing E. coli strains was established using multiplex-Polymerase Chain Reaction.

Results: The health care clinics in the Vhembe District generally complied with the basic WASH services guidelines according to the World Health Organisation. Although $80 \%$ of the clinics used borehole water which is classified as an improved water source, microbiological assessment showed that 38\% inside taps and 64\% outside taps from the clinic compounds had TC counts higher than guideline limits for safe drinking. Similarly, EC counts above the guideline limit for safe drinking water were detected in 17\% inside taps and 32\% outside taps from the clinic compounds. Pathogenic EAEC, EPEC, ETEC and EHEC strains were isolated in the collected water samples. Although improved sanitation infrastructures were present in most of the clinics, the sanitary conditions of these toilets were not up to standard. Waste systems were not adequately managed. A total of $90 \%$ of the clinics had hand washing basins, while only $61 \%$ of the clinics had soap present and only $64 \%$ of the clinics had adequate signs and posters reminding the staff, care givers and patients to wash their hands.
\end{abstract}

Conclusions: Various WASH aspects within the primary health care system in South Africa needs to be improved and corrected. A more rigorous system that is inclusive of all role players in the WASH sectors, with regular monitoring and training sessions, should be used.

Keywords: Escherichia coli, Hygiene, Public health care facilities, Sanitation, Water supply and quality

* Correspondence: natasha.potgieter@univen.ac.za

${ }^{1}$ Department of Microbiology, University of Venda, Thohoyandou, South

Africa

Full list of author information is available at the end of the article

(c) The Author(s). 2021 Open Access This article is licensed under a Creative Commons Attribution 4.0 International License, which permits use, sharing, adaptation, distribution and reproduction in any medium or format, as long as you give appropriate credit to the original author(s) and the source, provide a link to the Creative Commons licence, and indicate if changes were made. The images or other third party material in this article are included in the article's Creative Commons licence, unless indicated otherwise in a credit line to the material. If material is not included in the article's Creative Commons licence and your intended use is not permitted by statutory regulation or exceeds the permitted use, you will need to obtain permission directly from the copyright holder. To view a copy of this licence, visit http://creativecommons.org/licenses/by/4.0/. The Creative Commons Public Domain Dedication waiver (http://creativecommons.org/publicdomain/zero/1.0/) applies to the data made available in this article, unless otherwise stated in a credit line to the data. 


\section{Background}

The global action plan for WASH (water, sanitation and hygiene) in health care facilities state that by 2030 , every health care facility in every setting must have safely managed, reliable water, sanitation and hygiene facilities and practices to meet staff and patient needs in order to provide quality, safe people-centred care [1, 2]. However, several reports on WASH services/infrastructure and practices in health care facilities have shown disparities in the African region and other developing countries [3-9]. The practice of poor WASH in health care facilities can result in numerous consequences. It is estimated that health care associated infections (HAI) affect several millions of people every year with an estimated $15 \%$ of patients developing one or more infections during their visit and stay at health care facilities [10]. Improved WASH conditions at health care facilities establishes trust and encourage mothers to seek prenatal care and deliver in facilities rather than at home $[11,12]$. It is therefore vital to improve WASH services in primary health care facilities especially when looking at birth episodes and combating antimicrobial resistance [13, 14].

The WHO guideline definition for basic water services at health care clinics, state that the main water source must be an improved water source, located on the premises and the water should be available continuously [15]. Water is an essential element in the day-to-day activities of the workers in health care facilities. Enough water is needed for drinking, cooking, hand hygiene, showering and/or bathing, for cleaning rooms, beds, floors, toilets, sheets and laundry, and to reduce the risk of infections [16]. During the Ebola epidemic in West Africa during 2014-2016, the lack of water at health care facilities was a logistic challenge to contain the outbreak [17]. A study by Majuru et al., [18] has shown that intermittent or unreliable water supplies are associated with high number of gastrointestinal diseases in sub-Saharan Africa. Saxena et al., [19] and Adebe et al., [20] have both shown that health is compromised if ill patients visit a health care facility with unsafe water. In order to assess the microbiological safety of drinking water sources, indicator organisms such as Total coliform (TE) bacteria and Escherichia coli (EC) bacteria are used. Total coliform bacteria include species like the Escherichia spp., Klebsiella spp., Enterobacter spp. and Citrobacter spp. (to mention a few) which have been associated with disease outbreaks and infections globally [21, 22]. The presence of the EC bacteria in drinking water indicates a recent faecal-oral contamination since the organism can only survive for limited periods outside the host and can either be present due to unprotected water supply/source to the facility, or due to the improper faecal disposal in the facility that contaminates the water [23]. Pathogenic EC strains do not all carry the same public health profile, but they all have the potential to cause disease (most notably diarrhoea) and continue to present challenges to human health and cause morbidity and mortality worldwide [24, 25].

The WHO guideline definition for basic sanitation services in health care facilities recommend that sanitation services should be improved and usable (available, private and functional) facilities with dedicated toilets to staff, sex separated toilets with menstrual hygiene facilities and toilets for use by people with limited mobility [15]. As a basic human right, sanitation services in health care facilities are crucial for the delivery of highquality care for improved health, welfare and dignity of both patients and staff. In the absence of proper toilets, diseases can spread and therefore the sanitary management of excreta is vital to stop faecally transmitted pathogens from contaminating the environment around (inside and outside) the health facility [15].

The WHO definition for basic hygiene services state that the hand hygiene facilities must be available and functional at one or more points of care (points where care or treatment is delivered) and within $5 \mathrm{~m}$ from the toilet [15]. The prevention and control of infections and spread of germs in health care facilities are done through active hand hygiene measures practicing by staff and patients as well as the provision of hand washing stations with soap for patients and other [15, 26]. However, according to WHO [27], one in every four PHC facilities lack basic water services and many people are served by facilities without hand washing facilities. Musu et al., [28] have shown that organisms responsible for health care associated infections are frequently carried on the hands of health care workers. A study by Erasmus et al., [29] has shown that compliance with hand washing standards amongst health care providers is often low and may lead to disease transmission. Labi et al., [30] have shown that hand washing compliance amongst health care workers improve through proper and continued education, regular hygiene audits and feedback together with the provision of essential supplies like soap and disinfection solutions, displays of hand hygiene posters, visible and clear hand hygiene instructions and positive role modelling by senior staff and colleagues.

The WHO [15] guidelines recommend that wastes which is either infectious, chemically hazardous or radioactive must be managed in a suitable manner to prevent unsafe exposure to health care workers, patients, visitors, waste handlers and the public. Most wastes produced in health care facilities are not hazardous and can be disposed of along with general solid wastes [31, 32]. In South Africa waste management is multi-sectoral and involves not only the Department of Health (DOH) but also the Department of Environmental affairs (DEA). 


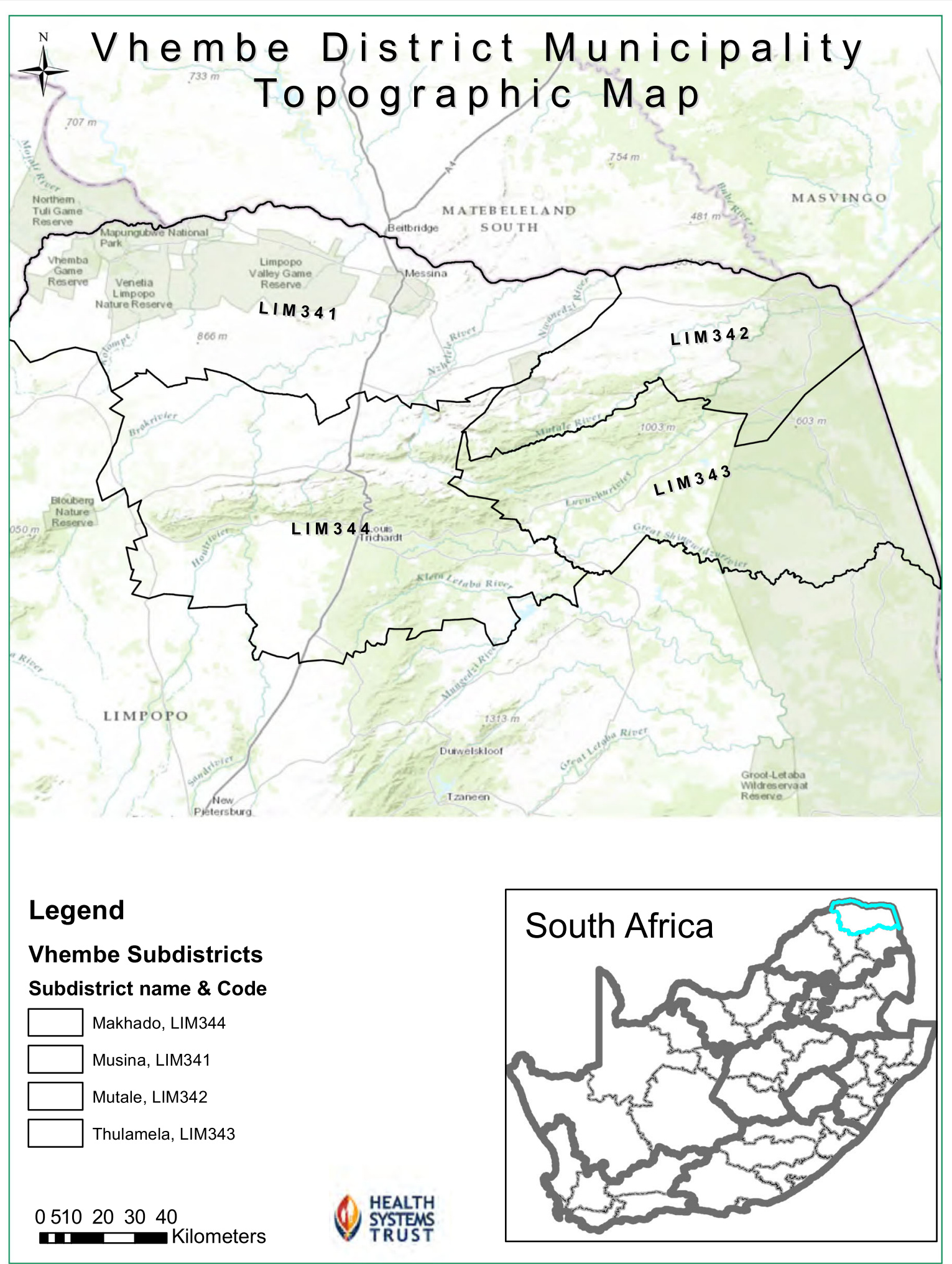

Source: Municipal Demarcation Board

Fig. 1 Vhembe District map indicating the four health sub-Districts [35] 
Table 1 Primary health care facilities in the Vhembe district [29-31]

\begin{tabular}{lllllll}
\hline $\begin{array}{l}\text { sub-District } \\
\text { Municipality }\end{array}$ & $\begin{array}{l}\text { Primary health } \\
\text { care clinics (PHC) }\end{array}$ & $\begin{array}{l}\text { Community } \\
\text { health centres }\end{array}$ & $\begin{array}{l}\text { District } \\
\text { hospitals }\end{array}$ & $\begin{array}{l}\text { Regional } \\
\text { hospital }\end{array}$ & $\begin{array}{l}\text { Mobile } \\
\text { services }\end{array}$ & $\begin{array}{l}\text { PHC clinic included } \\
\text { in study (\%) }\end{array}$ \\
\hline Makhado & 47 & 4 & 3 & 0 & 10 & $18(38 \%)$ \\
Thulamela & 49 & 3 & 2 & 1 & 10 & $24(49 \%)$ \\
Mutale & 16 & 1 & 0 & 0 & 3 & $6(38 \%)$ \\
Musina & 4 & 0 & 1 & 0 & 1 & $2(50 \%)$ \\
Total number & $\mathbf{1 1 6}$ & $\mathbf{8}$ & $\mathbf{6}$ & $\mathbf{1}$ & $\mathbf{2 4}$ & $\mathbf{5 0 ( 4 3 \% )}$ \\
\hline
\end{tabular}

The DEA has developed a policy that describes the guidelines for health care risk waste management (HCRW) and the standards for equipment to be used in it. From this guideline, the DOH in each province, extracts their own guideline document with clear description on every point of the management process within health care facilities [33]. The Health Professionals Council of South Africa [34] has also developed a HCWR management booklet with guidelines on various subcategories of wastes with clear role definitions for each health worker in the HCRW management chain with specific responsibilities clearly described.

The objective of this study was therefore to assess WASH infrastructure and practices in primary health care clinics in the Vhembe District in the Limpopo Province of South Africa.

\section{Methods}

\section{Study design and site selection}

The study was carried out during 2016-2017 in the Vhembe District in the northern part of the Limpopo Province in South Africa. The District covers 25,597 $\mathrm{km}^{2}$; have a total population of approximately $1,367,186$ people and consists of four health sub-Districts namely Musina, Mutale, Thulamela and Makhado (Fig. 1). The Vhembe district is among the poorest of 52 Districts in South Africa with high levels of unemployment, and mainly rural living conditions and $93,6 \%$ of the people are uninsured and dependant on the public health sector for care [35-37].

Table 1 indicates the number of primary health care (PHC) facilities available in the Vhembe sub-Districts and the number of primary health care clinics included in this study [35-37]. The health care clinics are well distributed within the Makhado and Thulamela sub-
District municipalities, while the Mutale and Musina sub-District Municipalities needs more health care facilities especially with the influx of foreign nationals through the Musina border post into the Limpopo Province. The clinics provide primary health care services through nurses and operate normally for $8 \mathrm{~h}$. In addition, some nursing staff may be required to sleep at or near the health care clinic in case of emergency calls. There are 116 government owned PHC facilities in the Vhembe District Municipality from which 50 (43\%) health care clinics were randomly selected for this study. Selfobservation and interviews with the manager of each health care clinic during a once off visit to each of these clinics, and a standardized WHO observational checklist [38] dealing with WASH conditions, availability, supply, sanitation, hygiene and waste management aspects were used to obtain information on water, sanitation and hygiene aspects of the health care clinics. Record reviews were used to collect supplementary information on patient loads.

\section{Microbiological quality assessment of water samples}

All water samples were collected in sterile $250 \mathrm{~mL}$ water collection bottles, put on ice and taken to the laboratory to be assessed within $5 \mathrm{~h}$ of collection. The presence of Total coliform (TC) bacteria and E. coli (EC) bacteria in water samples $(100 \mathrm{~mL})$ from all indoor and outdoor taps at the health care clinics were assessed by the most probable number (MPN) method using the Colilert ${ }^{\circ}$ Quanti-Tray/2000 system according to the manufacturer's instructions (IDEXX, Westbrook, Maine, USA). Pathogenic strains of the E. coli positive water samples were identified using a multiplex protocol performed in a Biorad Mycycler ${ }^{\mathrm{ma}}$ Thermal cycler with specific genes as described by Omar et al., [39].

Table 2 Presence and activities of WASH Committee/Board in the study health care clinics

\begin{tabular}{|c|c|c|c|c|c|}
\hline Indicator & n (\%) & Makhado & Thulamela & Mutale & Musina \\
\hline Committee present & $43 / 50(86 \%)$ & 17 & 19 & 6 & 1 \\
\hline Do the committee have a budget? & $13 / 50(26 \%)$ & 7 & 5 & 1 & 0 \\
\hline Does the committee have a maintenance plan for water facilities? & $16 / 50(32 \%)$ & 6 & 5 & 5 & 0 \\
\hline
\end{tabular}


Table 3 General information and statistics of the health care clinics $(n=50)$

\begin{tabular}{|c|c|c|c|c|}
\hline Indicator & Minimum & Maximum & Mean & Standard Deviation \\
\hline $\mathrm{Nr}$ of staff at PHC facilities & 10 & 74 & 24 & 15.34 \\
\hline Average number of out-patients seen by staff & 50 & 400 & 124.5 & 71.48 \\
\hline Average number of in-patients seen by staff & 0 & 10 & 0.36 & 1.56 \\
\hline Number of in-bed maternity bed capacity & 0 & 22 & 3.68 & 3.80 \\
\hline Average number of deliveries conducted in past 1 month & 0 & 40 & 6.86 & 7.36 \\
\hline Total number of deliveries in the past 12 months & 0 & 300 & 92.58 & 80.16 \\
\hline Total number of caesarean sections done in the last 12 months & 0 & 0 & 0 & 0 \\
\hline Total number of maternal deaths in the last 12 months & 0 & 0 & 0 & 0 \\
\hline
\end{tabular}

\section{Statistical analysis}

Bacterial counts and data from questionnaires were entered on Microsoft Excel spread sheets. Descriptive analytical frequencies, percentages and 95\% Confidence Intervals (CI) were used. Counts were summarised using geometric means and $95 \% \mathrm{CI}$ for water samples that tested positive.

\section{Results}

General background on health care facilities

A WASH committee which oversees activities and other WASH related aspects in the clinic was present in $86 \%$ $(43 / 50)$ of the health care clinics. Only 26\% (13/50) of the health care clinics used the budget provided for

Table 4 Water infrastructure and practices at the health care clinics $(n=50)$

\begin{tabular}{|c|c|c|c|c|c|}
\hline \multirow[t]{2}{*}{ Indicator } & \multirow{2}{*}{$\begin{array}{l}\text { Total } \\
\text { number }\end{array}$} & \multicolumn{4}{|c|}{ Vhembe sub-Districts } \\
\hline & & Makhado & Thulamela & Mutale & Musina \\
\hline \multicolumn{6}{|l|}{ Water source } \\
\hline Piped water into PHC facility & 27 & 4 & 17 & 4 & 2 \\
\hline Piped water into yard/compound & 1 & 0 & 1 & 0 & 0 \\
\hline Public stand (pipe/stand) & 1 & 0 & 1 & 0 & 0 \\
\hline Tube well/borehole & 40 & 17 & 19 & 3 & 1 \\
\hline Protected dug well & 0 & 0 & 0 & 0 & 0 \\
\hline Unprotected dug well & 0 & 0 & 0 & 0 & 0 \\
\hline Protected spring & 0 & 0 & 0 & 0 & 0 \\
\hline Unprotected spring & 0 & 0 & 0 & 0 & 0 \\
\hline Rainwater collection & 0 & 0 & 0 & 0 & 0 \\
\hline Cart with small tank/drum & 0 & 0 & 0 & 0 & 0 \\
\hline Tanker truck & 0 & 0 & 0 & 0 & 0 \\
\hline Surface water (river/dam/lake/pond/channel) & 0 & 0 & 0 & 0 & 0 \\
\hline \multicolumn{6}{|l|}{ Distance of main water supply point from clinic } \\
\hline At facility $(0 \mathrm{~m})$ & 40 & 15 & 20 & 5 & 0 \\
\hline Less than $200 \mathrm{~m}$ from clinic & 4 & 3 & 0 & 1 & 0 \\
\hline Less than $500 \mathrm{~m}$ from clinic & 2 & 0 & 2 & 0 & 0 \\
\hline $1 \mathrm{~km}$ from clinic & 1 & 0 & 0 & 0 & 1 \\
\hline$>1 \mathrm{~km}$ from clinic & 2 & 0 & 2 & 0 & 0 \\
\hline Other water points at clinic & 1 & 1 & 0 & 0 & 0 \\
\hline $\begin{array}{l}\text { Alternative option for water storage when water is } \\
\text { not available at water points }\end{array}$ & 47 & 16 & 24 & 6 & 1 \\
\hline \multicolumn{6}{|l|}{ Average queuing time at water points: } \\
\hline $0 \mathrm{~min}$ & 47 & 18 & 21 & 6 & 2 \\
\hline $1 \mathrm{~min}$ & 1 & 0 & 1 & 0 & 0 \\
\hline $2 \mathrm{~min}$ & 2 & 0 & 2 & 0 & 0 \\
\hline
\end{tabular}


Table 5 Water quality at health care facilities according to WHO risk criteria [40]

\begin{tabular}{lllllll}
\hline Indicator & Taps & Number of taps tested & $\begin{array}{l}\text { Safe } \\
{[\mathbf{0 ~ c f u / 1 0 0 ~} \mathbf{~ m l}]}\end{array}$ & $\begin{array}{l}\text { Low risk } \\
{[\mathbf{1 - 1 0} \mathbf{c f u} / \mathbf{1 0 0} \mathbf{~ m l ]}}\end{array}$ & $\begin{array}{l}\text { Intermediate risk } \\
{[\mathbf{1 0}-\mathbf{1 0 0} \mathbf{c f u} / \mathbf{1 0 0} \mathbf{~ m l}]}\end{array}$ & $\begin{array}{l}\text { High risk } \\
{[\geq \mathbf{1 0 0} \mathbf{c f u} / \mathbf{1 0 0} \mathbf{~ m l}]}\end{array}$ \\
\hline Total coliform & Inside taps & 48 & $14(29 \%)$ & $16(33 \%)$ & $8(17 \%)$ & $10(21 \%)$ \\
& Outside taps & 50 & $6(12 \%)$ & $12(24 \%)$ & $15(30 \%)$ & $17(34 \%)$ \\
\multirow{2}{*}{ E. coli } & Inside taps & 48 & $40(83 \%)$ & $6(13 \%)$ & $2(4 \%)$ & 0 \\
& Outside taps & 50 & $34(68 \%)$ & $13(26 \%)$ & $3(6 \%)$ & 0 \\
\hline
\end{tabular}

WASH related services while only $32 \%(16 / 50)$ of the health care clinics had a maintenance plan available to deal with WASH related aspects in the clinic (Table 2).

The health care clinics differed in size and operation (Table 3). The number of staff per clinic determined the size of the clinic and ranged between 10 and 74 staff members. Consultations included mostly out-patients who visited the health care clinics. Only four health care clinics had seen in-patients with a maximum of 10 per day. Generally, the health care clinics only allow a pregnant mother to stay for up to $6 \mathrm{~h}$ after giving birth. In cases of complications during or after birth, the mother and child are transferred to the nearest hospital. None of the clinics conducted any caesareans in the past 12 months. The health care clinics had no maternal or new-born deaths reported in the past 12 months.

\section{Provision of basic water services}

The health care clinics included in this study used either borehole/tube-well $(40 / 50 ; 80 \%)$ or piped water into the clinic $(27 / 50 ; 54 \%)$ as the main water source (Table 4$)$. All these water points on the clinic compound were used by both patients and staff as drinking water points.

Information on the average years of construction of the water sources on the compound were not readily available during the interviews. Only 50\% (25/50) of the health care clinics could provide information on the construction of the boreholes which were between 1 year and 30 years [mean: 11 years] and only $22 \%(11 / 50)$ of the health care clinics could provide information on the construction of the tap water pipelines which were between 2 years and 24 years [mean: 13 years]. Additionally, 94\% (47/50) of the health care clinics had a water storage tank. The biggest storage tank observed was of $25,000 \mathrm{~L}$ in size. This assured water availability if something happened to the main water source supply. Observations indicated that on average only $32 \%(16 / 50)$ of the health care clinics had functional water taps. Further observations indicated that on average the distance that in-patients had to walk to the nearest tap were between $19 \mathrm{~m}$ and $700 \mathrm{~m}$ [mean distance: $20 \mathrm{~m}$ ]. The health care clinics also kept water storage containers. Observations of theses storage containers indicated that 80\% (40/50) of the health care clinics had clean water storage containers.

\section{Microbiological quality of available water}

During the once off visit to each health care clinic, water samples were collected and assessed for Total coliform (TC) bacteria and E. coli (EC) bacteria counts per $100 \mathrm{ml}$ water sample. In total, samples were collected from 48 inside taps and 50 outside taps from all clinics. The TC

Table 6 The detection of pathogenic strains of E. coli in the water sources used by the health care clinics

\begin{tabular}{|c|c|c|c|c|c|}
\hline \multirow{2}{*}{$\begin{array}{l}\text { E. coli pathotypes } \\
\text { detected in water } \\
\text { samples }\end{array}$} & \multirow{2}{*}{$\begin{array}{l}\text { Number of water samples } \\
\text { containing this pathogenic } \\
\text { strain }\end{array}$} & \multicolumn{4}{|c|}{ Vhembe sub-Districts } \\
\hline & & Makhado & Thulamela & Mutale & $\overline{\text { Musina }}$ \\
\hline \multicolumn{6}{|c|}{ Outside tap water samples } \\
\hline EAEC & $75 \%(12 / 16)$ & 5 & 4 & 2 & 1 \\
\hline ETEC & $75 \%(12 / 16)$ & 5 & 4 & 2 & 1 \\
\hline EPEC & $50 \%(8 / 16)$ & 3 & 3 & 1 & 1 \\
\hline EHEC & $25 \%(4 / 16)$ & 1 & 2 & 1 & 0 \\
\hline EIEC & $0 \%(0 / 24)$ & 0 & 0 & 0 & 0 \\
\hline \multicolumn{6}{|c|}{ Inside tap water samples } \\
\hline ETEC & $100 \%(8 / 8)$ & 2 & 4 & 2 & 0 \\
\hline EPEC & $88 \%(7 / 8)$ & 2 & 3 & 2 & 0 \\
\hline EAEC & $75 \%(6 / 8)$ & 2 & 3 & 1 & 0 \\
\hline EHEC & $38 \%(3 / 8)$ & 0 & 2 & 1 & 0 \\
\hline EIEC & $0 \%(0 / 8)$ & 0 & 0 & 0 & 0 \\
\hline
\end{tabular}


Table 7 Sanitation infrastructure and practices at health care clinics $(n=50)$

Indicator
Main type of toilet/excreta disposal facility:
Flush/pour toilet to piped sewer system/septic tank etc
VIP toilet
Pit latrine with slab
Pit latrine without slab/open pit
Bucket
No facilities/bush/field
Ecosan
Location of toilet
Separate from PHC facility
Within PHC facility
Both separated and within PHC facility

The toilet facilities are constructed to accommodate people with disabilities

Sanitary condition of toilet facility at time of inspection

Cleanliness of seat [absence of dirt/urine/faecal matter]

Cleanliness of toilet hole (It is covered)

Cleanliness of wall [no graffiti/urine/faecal matter]

Cleanliness of floor [no litter/urine/faecal matter]

Smell [no foul odour]

Cleaning/cleansing materials in toilet (soap/toilet paper/ sanitary tissue]

Vhembe sub-Districts

\begin{tabular}{llll}
\hline Makhado & Thulamela & Mutale & Musina
\end{tabular}

\section{n}

Thulamela

24

20

7

0

0

0

0

0

1
0
23
24

24

$\begin{array}{lll}11 & 3 & 2 \\ 9 & 4 & 0 \\ 12 & 4 & 1 \\ 20 & 6 & 2 \\ 12 & 2 & 0 \\ 14 & 4 & 1\end{array}$

11
14
14
17
8
10

Mutale

\section{How often are toilets cleaned?}

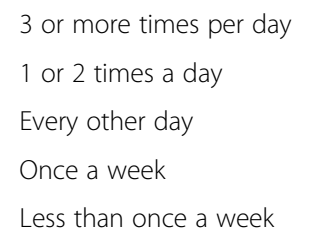

\section{Who cleans the toilets?}

Hired cleaners
Patient care takers
health care workers
Community volunteers

Musina

ondition of immediate area around the toilet building and entrance to the toilet

Grass present

15
2
0
0
0

16
8
0
0
0

$\begin{array}{ll}4 & 1 \\ 2 & 1 \\ 0 & 0 \\ 0 & 0 \\ 0 & 0\end{array}$

Level of faecal matter in pit

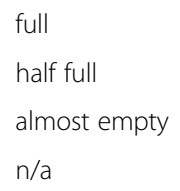

Is there a mechanism to empty toilets or provide an alternative if toilets are full? 
Table 7 Sanitation infrastructure and practices at health care clinics $(n=50)$ (Continued)

\begin{tabular}{|c|c|c|c|c|c|}
\hline \multirow[t]{2}{*}{ Indicator } & \multirow[t]{2}{*}{$\mathbf{n}$} & \multicolumn{4}{|c|}{ Vhembe sub-Districts } \\
\hline & & Makhado & Thulamela & Mutale & Musina \\
\hline \multicolumn{6}{|l|}{ Mechanism used to empty pit } \\
\hline Flush/drainage of VIP & 30 & 10 & 15 & 5 & 0 \\
\hline Flush/drainage of VIP/Use of pit latrine & 1 & 0 & 1 & 0 & 0 \\
\hline Never experienced full pit & 7 & 2 & 4 & 0 & 1 \\
\hline Use sanitation in next building/section & 2 & 1 & 0 & 1 & 0 \\
\hline VIP is used if there is no water for flush toilets & 1 & 0 & 1 & 0 & 0 \\
\hline
\end{tabular}

counts for both inside and outside taps ranged from 0 $\mathrm{cfu} / 100 \mathrm{~mL}$ to $>2420 \mathrm{cfu} / 100 \mathrm{~mL}$ [mean TC count for inside taps: $249 \mathrm{cfu} / 100 \mathrm{~mL}$; mean TC count for outside taps: $281 \mathrm{cfu} / 100 \mathrm{~mL}$ ]. The EC counts for inside taps ranged from $0 \mathrm{cfu} / 100 \mathrm{~mL}$ to $649 \mathrm{cfu} / 100 \mathrm{~mL}$ [mean EC count: $16 \mathrm{cfu} / 100 \mathrm{~mL}$ ]. The EC counts for outside taps ranged from $0 \mathrm{cfu} / 100 \mathrm{~mL}$ to $52 \mathrm{cfu} / 100 \mathrm{~mL}$ [mean EC count: $2 \mathrm{cfu} / 100 \mathrm{~mL}$ ]. Only $10 \%(5 / 50)$ of the heath care clinics reported to be treating the water before drinking which included chlorination, filtration and receiving treated water directly from the treated municipal supply.

Table 5 indicates the health risk criteria according to the WHO [40] of all water samples collected from the inside and outside taps of the health care clinics. In this study, 62\% (30/48) water samples from inside taps and $36 \%(18 / 50)$ outside taps had between 0 and $10 \mathrm{cfu} / 100$
$\mathrm{mL}$ TC counts and were considered safe to use. However, 38\% (18/48) inside taps and 64\% (32/50) outside taps had $\mathrm{TC}$ counts in the unacceptable range which made them unsafe for human consumption. The water samples from $83 \%(40 / 48)$ inside taps $68 \%$ (34/50) outside taps had $0 \mathrm{cfu} / 100 \mathrm{~mL}$ for $\mathrm{EC}$ and was considered safe as a drinking water source. However, 24 tap water samples $[17 \%(8 / 48)$ inside taps and 32\% (16/50) outside taps] had EC counts indicating a high risk of infectious disease and unacceptable for human consumption [33].

Pathogenic strains of $E$. coli were detected in all the $E$. coli positive water samples $(n=24)$ and $92 \%(22 / 24)$ of the water samples had more than one pathogenic $E$. coli strain (Table 6). In the outside water samples tested, the most dominant pathogenic strains included EAEC (75\%), ETEC (75\%) and EPEC (50\%), while ETEC (100\%), EPEC

Table 8 Hand washing infrastructure and practices at the health care clinics $(n=50)$

\begin{tabular}{|c|c|c|c|c|c|}
\hline \multirow[t]{2}{*}{ Indicator } & \multirow[t]{2}{*}{ n } & \multicolumn{4}{|c|}{ Vhembe sub-District } \\
\hline & & Makhado & Thulamela & Mutale & Musina \\
\hline Hand washing facilities present at PHC facility & 48 & 18 & 23 & 6 & 1 \\
\hline \multicolumn{6}{|l|}{ Main type of hand washing facility } \\
\hline Wash basin and running water & 45 & 17 & 21 & 6 & 0 \\
\hline Wash basin and buckets/small jerry cans/bottle accessed water & 3 & 1 & 1 & 1 & 0 \\
\hline Small jerry can and water & 0 & 0 & 0 & 0 & 0 \\
\hline Bottle with water & 0 & 0 & 0 & 0 & 0 \\
\hline Tippy tap & 1 & 0 & 1 & 0 & 0 \\
\hline Other & 3 & 0 & 2 & 0 & 1 \\
\hline \multicolumn{6}{|l|}{ Location of hand washing facility } \\
\hline Inside toilet unit & 25 & 9 & 12 & 3 & 1 \\
\hline Immediately outside toilet facility & 38 & 12 & 19 & 6 & 1 \\
\hline Inside PHC clinic building & 2 & 0 & 2 & 0 & 0 \\
\hline Outside PHC clinic building & 2 & 1 & 0 & 0 & 1 \\
\hline \multicolumn{6}{|l|}{ Evidence of hand washing practices } \\
\hline $\begin{array}{l}\text { Good [presence and availability of soap and water/patients and } \\
\text { staff are reminded to wash hands] }\end{array}$ & 31 & 15 & 13 & 2 & 1 \\
\hline $\begin{array}{l}\text { Poor [water available/ no soap available or present/ no evidence to } \\
\text { remind patients and staff to wash hands] }\end{array}$ & 17 & 3 & 9 & 4 & 1 \\
\hline Very poor [no water/no soap/ no reminder to wash hands] & 2 & 0 & 2 & 0 & 0 \\
\hline
\end{tabular}


Table 9 Waste disposal infrastructure and practices in the health care clinics $(n=50)$

\begin{tabular}{|c|c|c|c|c|c|}
\hline \multirow[t]{2}{*}{ Indicator } & \multirow[t]{2}{*}{$\mathbf{n}$} & \multicolumn{4}{|c|}{ Vhembe sub-District } \\
\hline & & Makhado & Thulamela & Mutale & Musina \\
\hline Is the waste separated? & 50 & 18 & 24 & 6 & 2 \\
\hline \multicolumn{6}{|l|}{ Disposal of rubbish/waste } \\
\hline Burned on/or next to facility compound & 29 & 12 & 16 & 1 & 0 \\
\hline Buried on/next to facility compound & 0 & 0 & 0 & 0 & 0 \\
\hline Garbage dump site on/next to facility compound & 1 & 0 & 1 & 0 & 0 \\
\hline Transported of the facility compound & 49 & 18 & 23 & 6 & 2 \\
\hline \multicolumn{6}{|l|}{$\begin{array}{l}\text { Types of solid waste disposal containers provided by } \\
\text { facility to patients/caregivers }\end{array}$} \\
\hline Garbage container inside PHC facility only & 4 & 3 & 1 & 0 & 0 \\
\hline Garbage container on compound only & 3 & 1 & 1 & 0 & 1 \\
\hline Garbage container inside PHC facility and on compound & 44 & 14 & 22 & 6 & 2 \\
\hline No garbage containers provided & 0 & 0 & 0 & 0 & 0 \\
\hline
\end{tabular}

(88\%) and EAEC (75\%) strains were the most dominant pathogenic strains detected in the inside water samples tested. No EIEC strains were detected in any of the water samples.

\section{Provision of basic sanitation services}

Toilets in the health care clinics included flush toilets (49/ 50; 98\%) and VIP toilets (41/50; 82\%) with some health care clinics still using pit latrines (9/50; 18\%). Toilets in the study cohort were separated for males and females [mean number of toilets per sex: 2 for males and 3 for females] and were situated either inside or outside the clinic building (Table 7).

The toilets were reported to be cleaned between 1 to more than 3 times per day by either the health care workers $(58 \%)$, hired cleaners $(40 \%)$ or volunteering community members (6\%). A total of $96 \%$ (48/50) of the health care clinics reported that the toilets were accessible during clinic operation hours. Observations showed that the distance the inpatients had to walk to reach the toilets ranged from $0 \mathrm{~m}$ to $500 \mathrm{~m}$ [mean distance: $12 \mathrm{~m}$ ]. Information on the construction of the toilets were also not easy to obtain. Only 30\% (15/49) health care clinics could report that the flush toilets were constructed between 5 years and 36 years ago [mean time of construction: 21 years], while only $42 \%(17 / 41)$ of the health care clinics could report that the VIP toilets were constructed between 1 and 30 years [mean time of construction: 8 years]. Proper lighting around the toilets were observed in 90\% (45/50) of the health care clinics and 94\% (47/50) of the health care clinics had proper locks and doors on the toilet cubicles for privacy and dignity. This study did not investigate the presence of waste bins in the female toilets.

\section{Provision of basic hygiene services}

Hand washing basins with running water were observed in $90 \%(45 / 50)$ of the health care clinics (Table 8$)$. The hand washing facility was either inside $(25 / 50 ; 50 \%)$ the toilet facility or just outside $(38 / 50 ; 76 \%)$ the toilet facility. Evidence of good hand washing practices which included the presence and availability of soap and water and signs or posters reminding patients and staff to wash hands ranged from good $(31 / 50 ; 62 \%)$ to very poor (2/ $50 ; 4 \%)$ where no water and no soap and no signs or posters to remind staff and patients to wash their hands were observed in the health care clinic. Overall, signs and posters to encourage hand washing practices were only present in $64 \%(34 / 50)$ of the health care clinics. During the interviews, a total of $98 \%(49 / 50)$ of the health care clinics reported that they do give lectures on how to wash your hands to caregivers and patients.

\section{Provision of basic health care waste management services}

All the health care clinics separated the medical and solid wastes (Table 9). The distance of the solid waste disposal area from the main health care clinic building ranged between 0 and $500 \mathrm{~m}$ [mean distance: $61.7 \mathrm{~m}$ ].

The majority $98 \%(49 / 50)$ of health care clinics transported the waste of the compound and 58\% (29/50) of the health care clinics burned the solid waste on the compound. None of the health care clinics buried the waste in the facility compound. The health care clinics all used the garbage site and burning method for the solid wastes when the disposal bins were full, and the waste collecting company did not collect the wastes. Additionally, 88\% (44/50) of the health care clinics made sure that waste disposal bins were present on the compound as well as inside the health care clinic building. Observations showed that 72\% (36/50) of the health care clinics had a clean and properly maintained compound where the grass was cut, and no litter was laying around the compound. All health care clinics reported to maintain their compound at least once a month. 


\section{Discussion}

The Sustainable Development Goal (SDG) targets for 2030 calls for the provision of affordable and quality universal health care coverage and the availability and sustainable management of water and sanitation for all [27, 41]. In South Africa, the national health policies do align with the 2030 SDG targets and prominently states the importance of health care for all her people [42-44]. The government remains accountable to provide good WASH infrastructure and should monitor and benchmark services and give training on practicing that was benchmarked in all health care facilities for good return on investment. The health care provision within South Africa is variable nationally. It is estimated that approximately $80 \%$ of the population in South Africa depend on the public health sector [45]. This increase the strain the primary health care system is taking with the statistics estimating that approximately 13,718 patients per clinic is recorded [45]. The strain includes (among other aspects) a shortage of medical doctors and nurses; infrastructure that is not maintained and poor record keeping [46-49].

A total of $80 \%$ of the health care clinics used borehole water which is classified by the WHO as an improved water source [3]. However, microbiological quality of samples taken from all the functional inside and outside taps on the clinic compound showed that many of the taps were providing water with $\mathrm{TC}$ and $\mathrm{EC}$ counts higher than WHO and South African water quality guideline counts for safe drinking water [40, 50, 51]. Other studies in developing countries globally have also shown that improved water sources at health care facilities do not necessarily guarantee safe water [6, 52-54]. A study by du Preez [55] assessing the water quality in health care facilities in the Mopani district of South Africa, who mainly used boreholes as a primary water source, showed that $55 \%$ of water samples collected from inside taps, outside taps and storage water containers had TC counts exceeding $10 \mathrm{cfu} / 100 \mathrm{~mL}$ and EC bacteria were found in $29 \%$ of the collected water samples. Other studies carried out in the rural areas in the Vhembe region have also showed that drinking water sources had unacceptable counts for TC and EC bacteria [56-58]. The most frequent $E$. coli pathogenic strains detected in the water samples collected from inside and outside taps on the clinic compound, included EPEC, ETEC and EAEC strains. Several studies that assessed water sources in the Vhembe District have showed the prevalence of these pathogenic strains $[56,59,60]$. Similarly, studies that screened stools in the Vhembe District have also showed that these strains are very prevalent in stools of children suffering from diarrhoea [61-63]. A study done by Kong et al., [64] estimates that EAEC causes acute and chronic diarrhoea and is a major contributor to global traveller's diarrhoea. ETEC is one of the pathogenic agents that causes acute diarrhoea in developing countries for children under the age of five [65]. EPEC is subdivided into two types, typical (tEPEC) and atypical (aEPEC). Typical EC contains a virulence plasmid in which the bundle-forming pilus encoding (bfp) is present, while atypical EC strain does not have the bfp adherence factor [66]. In developing and developed countries, atypical EPEC is an emerging diarrheal causative agent [67] and people infected with aEPEC suffer from persistent diarrhoea [68]. During this study it was also reported from the staff that very few of the health care clinics treat the water available to the clinic. Water treatment is an aspect that should be promoted to ensure the best possible quality water and should be practiced in all the primary health care facilities in South Africa where continuous water safety is not guaranteed. There are several commercial water quality tests available globally which are inexpensive, give rapid results and are easy to operate (such as the CBT test) which the staff and caregivers can use themselves to test water samples on a regular basis and do treatment for the provision of safe drinking water [69].

The study did not evaluate actual hand washing practices of staff at the health care clinics, but it did assess the presence of hand washing basins, presence of soap and presence of posters or signs indicating or reminding staff and patients of the importance of hand washing. This study did show that washing facilities for people to wash their hands after using the toilets, were present on the inside of $72 \%$ of the toilets and just outside $50 \%$ of the toilets. Sanitation observation during the clinic visits showed that the sanitary conditions (eg cleanliness etc) were not up to standard and should be given attention to, especially with regards to cleanliness of the toilet seats. Several studies have shown that pathogenic bacterial strains do survive on toilet seats and can be a health risk to vulnerable individuals [70]. Female toilets at the health care clinics were clearly identified with signs, were separated from the male toilets and had doors with locks to ensure privacy and dignity. The sanitary conditions of toilets in all clinics should be scrutinized and improved efforts to see that hand washing practices are improved at the health care facilities, should be implemented. Several studies have showed that proper hand hygiene practices decrease the likelihood that staff will pass pathogens to and between patients during consultation and it is estimated that it can lower infections between 23 to $53 \%$ and reduce neonatal mortality by $19 \%[10,71,72]$. Specific and clear visible signs and posters reminding people to practice hand hygiene, should be present at hand basins together with soap dispensers containing soap for use.

During this study it was observed that waste management policies were not always followed. Several studies 
have showed that improper waste management from cholera infected patients and staff can lead to faecal contamination of equipment within the health care facility and can cause fatal cholera outbreaks [73, 74]. A recent study by Oloniya et al., [75] on the efficiency of health care risk waste management in 15 rural health care facilities in the Vhembe district has noted mismanagement at different points along the waste management chain. These included poor segregation, overfilling of waste bins, inappropriate transportation and storage of wastes in sub-standard storage rooms which showed the problems currently experienced in health care facilities.

The limitations of the study included the following aspects: only 50 out of 116 health care clinics of the Vhembe District were included; the data collected through interviews with the clinic managers in this study could have been biased or not totally accurate and the study also does not offer assessment on changes of water quality or on water infrastructure repairs over time. Nevertheless, the strengths of the study included the direct systematic and objective observations by the research team which provided valuable insight into WASH related activities in health care facilities in South Africa.

\section{Conclusions}

In conclusion, the present study has showed that several issues in WASH infrastructure and practices at health care facilities in the Vhembe district of South Africa needs improvement: water sources are not necessarily safe water sources and the water sector needs to do more to improve water quality and not just access; the sanitary conditions of toilets in all clinics should be scrutinized and upgraded; hygiene behaviour change training/workshops to improve hand washing practices at the health care facilities should be implemented and proper health risk waste management procedures should be followed. Therefore, continuous engagement and improved coordination between different ministries and stakeholders are important in order to improve WASH infrastructure and practices at health care facilities in rural areas of South Africa.

\footnotetext{
Abbreviations

cfu: colony forming units; Cl: Confidence Intervals; E. coli: Escherichia coli; DEA: Department of Environmental Affairs; DOH: Department of Health; EAEC: Enteroadhesive E. coli; EC: E. coll; EAEC: Enteroaggregrative E. colli; EHEC: Enterohaemorraghic E. coli; EIEC: Enteroinvasisve E. coli;

EPEC: Enteropathogenic E. coli; ETEC: Enterotoxigenic E. coli; HAl: Healthcare Associated Infections; HCRW: Health Care Risk Waste Management; km: kilometer; mL: milliliter; MPN: most probable number; mPCR: multiplexPolymerase Chain Reaction; PHC: Public Health Care; SA: South Africa; SDG: Sustainable Development Goal; spp.: species; TC: Total coliform; WASH: Water, Sanitation and Hygiene; WHO: World Health Organisation
}

\section{Acknowledgments}

The authors wish to acknowledge the training of the student in molecular analysis of strains by the Water and Health Research Unit (University of
Johannesburg, South Africa), and the contributions by the health care providers.

\section{Authors' contributions}

NP designed the study protocol; NTB carried out the field and laboratory work; NP and ANT supervised the student and assisted in the analysis and interpretation of the data; PJB assisted in statistical analysis of data; NP, NTB, ANT and PJB contributed on the draft manuscript and revision of manuscript. All authors have read and approved manuscript,

\section{Funding}

This study was funded through a grant by the Wellcome Trust (UK) given to the SNOWS Consortium (http://www.africansnows.org/). The Wellcome Trust did not participate in the design of the study, data collection, analysis and interpretation of the data, or in the writing of the manuscript.

\section{Availability of data and materials}

The datasets used and analysed during the current study are available from the corresponding author on reasonable request.

\section{Ethics approval and consent to participate}

Written permission and informed consent for visits to the primary health care clinics and the use of questionnaires to obtain information was obtained from Vhembe District Office of the Department of Health in the Limpopo Province (Ref. 4/2/2). The study was approved in totality by the Ethics committee of the University of Venda (Ref. SMNS/13/MBY).

\section{Consent for publication}

Not applicable.

\section{Competing interests}

None.

\section{Author details}

${ }^{1}$ Department of Microbiology, University of Venda, Thohoyandou, South Africa. ${ }^{2}$ Research Office, Faculty of Health Sciences, University of Pretoria, Pretoria, South Africa.

Received: 19 July 2020 Accepted: 7 December 2020

Published online: 04 January 2021

\section{References}

1. WHO and UNICEFF Joint Monitoring Programme. Progress on drinking water and sanitation: 2014 update. WHO Press, Geneva, Switzerland: World Health Organization; 2.

2. Cronk R, Slaymaker T, Bartram J. Monitoring drinking water, sanitation and hygiene in non-household settings: priorities for policy and practice. Int J Hyg Environ Health. 2015;218:694-703.

3. WHO. Water, sanitation and hygiene in health care facilities: status in low and middle income countries and the way forward. Geneva, Switzerland: WHO Press; 2015. ISBN 9789241508476

4. Hsia RY, Mbembati NA, MacFarke S, Kruk ME. Access to emergency and surgical care in sub-Saharan Africa: the infrastructure gap. Health Policy Plan. 2012;27(3):234-44.

5. WHO. UN-water global annual assessment of sanitation and drinking water (GLAAS) 2012 report: the challenge of extending and sustaining services. Geneva, Switzerland: WHO Press; 2012.

6. Guo A, Bowling JM, Bartram J, Kayser G. Water, sanitation and hygiene in rural health-care facilities: a cross sectional study in Ethiopia, Kenya, Mozambique, Rwanda, Uganda and Zambia. Am J Trop Med Hyg. 2017; 97(4):1033-42.

7. Huttinger A, Dreibelbis R, Kayigamba F, Ngabo F, Mfura L, Merryweather B, Cardon A, Moe C. Water, sanitation and hygiene infrastructure and quality in rural health care facilities in Rwanda. MBC Health Serv Res. 2017. https:// doi.org/10.1186/s12913-017-2460-4

8. Mulongo EG, Matte M, Wesuta A, Bagenda F, Apecu R, Ntaro M. Water, sanitation and hygiene service availability at rural health care facilities in southwestern Uganda. J Environ Public Health. 2018. https://doi.org/10. 1155/2018/5403795.

9. Odagiri M, Azhar K, Cronin AA, Gressando Y, Hidayat I, Utami W, Widowati K, Roshita A, Soeharno R, Warouw SP, Ardhiatie. Water, sanitation and hygiene 
services in public health-care facilities in Indonesia: adoption of World Health Organization/united Nation's Children's fund service ladders to national sets for a sustainable development goal baseline assessment. Am J Med Hygiene. 2018;99(2):546-51.

10. Allegranzi B, Nejad S, Combescure C, Graafmans W, Attar H, Donaldson L. Burden of endemic health care associated infection in developing countries: systematic review and meta-analysis. Lancet. 2011;377:228-41.

11. Russo ET, Sheth A, Menon M, Wannemuehler K, Weinger M, Kudzala AC, Tauzie B, Masuku HD, Msowoya TE, Quick R. Water treatment and handwashing behaviors among non-pregnant friends and relatives of participants in an antenatal hygiene promotion program in Malawi. Am J Trop Med Hygiene. 2012;86(5):860-5.

12. Bartram J, Cronk R, Montgommery M, Gordon B, Neira M, Kelley E, Velleman Y. Lack of toilets and safe water in health-care facilities. Bull World Health Organ. 2015;93:210.

13. Nejad SB, Allegranzi B, Syed SB, Ellis B, Pittet D. Health-care associated infection in Africa: a systematic review. Bull World Health Organ. 2011;89:757-65.

14. Cronk R, Bartram J. Environmental conditions in health care facilities in lowand middle-income countries: coverage and inequalities. Int J Hyg Environ Health. 2018;221:409-22.

15. WHO. Water, sanitation and hygiene in health care facilities: practical steps to achieve universal access. Geneva, Switzerland: WHO Press; 2019. Licence: CC BY-NC-SA $3.0 \mathrm{IGO}$.

16. Watson J, Mello-Guyett LD, Flynn E, Falconer J, Esteves-Mills J, Prual A, Hunter $\mathrm{P}$, Allegranzi B, Montgomery $\mathrm{M}$, Cumming O. Interventions to improve water supply and quality, sanitation and handwashing facilities in health care facilities, and their effect on health care associated infections in low-income and middle-income countries: a systematic review and supplementary scoping review. BMJ Glob Health. 2019;4:e001632. https:// doi.org/10.1136/bmjgh-2019-001632.

17. $\mathrm{WHO}$ and UNICEFF Joint Monitoring Programme. Progress on sanitation and drinking water - 2017 update and SDG baseline. Geneva, Switzerland: WHO Press; 2017. World Health Organization.

18. Majuru B, Suhrcke M, Hunter P. Reliability of water supplies in low and middle income countries: a structured revies of definitions and assessment criteria. J Wate Sanitation Hygiene Dev. 2018. https://doi.org/10.2166/washdev.2018.174.

19. Saxena G, Bharagava RN, Kaithwas G, Raj A. Microbial indicators, pathogens and methods for their monitoring in water environment. J Water Health. 2015. https://doi.org/10.2166/wh.2014.275

20. Adebe L, Karon AJ, Koltun AJ, Cronk RD, Bain RES, Bartram J. Microbial contamination of non-household drinking water sources: a systematic review. J Water Sanitation Hygiene Dev. 2018. https://doi.org/10.2166/ washdev.2018.080.

21. Pal P. Detection of coliforms in drinking water and its effect on human health - a review. Int Lett Nat Sci. 2014;12:122-31.

22. Bilgin H, Sarmis A, Tigen E, Soyletir G, Mulazimoglu L. Delftia acidovoranns: a rare pathogen in immunocompetent and immunocompromised patients. Can J Infect Dis Med Microbiol. 2015;26(5):277-9.

23. Bueris V, Sircili MP, Taddei CR, Santos MFD, Franzolin MR, Martinez MB, Ferrer SR, Barreto ML, Trabulsi LR. Detection of diarrheagenic Escherichia coli from children with and without diarrhoea in Salvador, Bahia, Brazil. Mem Inst Oswaldo Cruz. 2007;102(7):839-44.

24. Prager $R$, Lang $C$, Aurass $P$, Fruth $A$, Tietze E, Flieger $A$. Two novel EHEC/EAEC hybrid strains isolated from human infections. PLoS One. 2014;9(4):e95379.

25. Nyholm O, Heinikainen S, Pelkonen S, Hallanvuo S, Haukka K, Siitonen A. Hybrids of Shigatoxigenic and Enterotoxigenic Escherichia coli (STEC/ETEC) among human and animal isolates in Finland. Zoonoses Public Health. 2015. https://doi.org/10.1111/zph.12177

26. Johnson RC, Boni G, Borogui Y, Sopoh GE, Houndonougbo EA, Agossadou D, Diez G, Boko M. Assessment of water, sanitation and hygiene practices and associated factors in Buruli ulcer endemic district in Benin (West Africa). BMC Public Health. 2015;15:801.

27. WHO. In: Adams J, Bartram J, Chartier Y, editors. Essential environmental health standards in health care. Geneva, Switzerland: WHO Press; 2008

28. Musu M, Lai A, Mereu NM, Galletta M, Campagna M, Tidore M, Piazza MF, Spada L, Massidda MV, Comlombo S, Muru P, Coppola RC. Assessing hand hygiene compliance among health care workers in six intensive care units. J Prev Med Hygiene. 2017;58:E231-7.

29. Erasmus V, Daha TJ, Brug H, Richardus JH, Bebrendt MD, Vos MC, Van Beeck EF. Systematic review of studies on compliance with hand hygiene guidelines in hospital care. Infect Control Hosp Epidemiol. 2010;31:283-94.
30. Labi AK, Obeng-Nkrumah N, Nuertey BD, Issahaku S, Ndiaye NF, Baffoe P, Dancun D, Wobil P, Enweronu-Lanyea. Hand-hygien practices and perceptions among healthcare workers in Ghana: a WASH intervention study. J Infect Dis Dev Countries. 2019;13(12):1076-85.

31. WHO. Safe management of wastes from health care facilities: a summary. Geneva, Switzerland: WHO Press; 2011. (WHO/FWCMSH/17.05).

32. WHO. Essential environmental health standards in health care. In: Adams J, Bartram J, Chartier Y, editors. . Geneva, Switzerland: WHO Press; 2017. ISBN 9789241547239.

33. Maseko Q. Critical evaluation of medical wastes management policies, processes and practices in selected rural hospitals in the eastern Capr. Master's thesis. Grahamstown, South Africa: Rhodes University; 2014.

34. Health Professional council of South Africa. Guidelines for good practice in the health care profession. Guidelines for the management of health care waste; Booklet 12; Health Professional Council of South Africa. Pretoria: HPCSA Publishing; 2016.

35. Massyn N, English R, McCracken P, Ndlovu N, Gerritsen A, Bradshaw D, Groenewald P. Disease profile for Vhembe Health District Limpopo. Pretoria, South Africa: Health Systems Trust. Department of Health; 2015.

36. Mukwevho N. (2016). New clinics in rural Vhembe to offer maternity services. URL: https://health-e.org.za/2016/11/11/newly-opened-clinics-ruralvhembe-villages-offer-maternity-services/. Accessed Dec 2016.

37. Massyn N, Peer N, English R, Padarath A, Barron P, Day C. District health barometer 2015/2016. Pretoria, South Africa: Health Systems Trust. Department of Health; 2017

38. World Health Organization and the United Nations Children's Fund. Core questions and indicators for monitoring WASH in health care facilities in the Sustainable Development Goals. Geneva: WHO and UNICEF; 2018. Licence: CC BY-NC-SA 3.0 IGO.

39. Omar KB, Potgieter N, Barnard TG. Development of rapid screening method for detection of pathogenic E. coli using a combination of Colilert Quantitrays/2000 and PCR. Water Sci Technol Water Supply. 2010;1:7-13.

40. WHO. Guidelines for drinking-water quality. $4^{\text {th }}$ ed. Geneva, Switzerland: World Health Organization; 2011.

41. World Health Organization and the United Nations Children's Fund. WASH in health care facilities: Global Baseline Report 2019. Geneva: WHO and UNICEF; 2019. Licence: CC BY-NC-SA 3.0 IGO.

42. Department of Health $(\mathrm{DOH})$. The primary health care package for South Africa - a set of norms and standards. Pretoria, South Africa: Department of Health; 2000.

43. Department of Health (DOH). A policy on quality in health care for South Africa. Pretoria, South Africa: Department of Health; 2007.

44. Department of Health (DOH). Department of health. Pretoria: South Africa; 2015.

45. Statistics SA. Census 2011 statistical release - P0301.4/Statistics South Africa. Pretoria: StatsSA; 2011.

46. Scheffler E, Visagie S, Schneider M. The impact of health service variables on healthcare access in a low resourced urban setting in the Western cape, South Africa. Afr J Prim Health Care Fami Med. 2015;7(1). https://doi.org/10. 4102/phcfm.v7i1.820.

47. Health-e News. (2004). Limpopo: limping behind in health care. Health-e news. URL: https://health-e.org/2004/03/26/limpopo-limping-behind-inhealth-care/. Accessed May 2020.

48. Health-e News. (2013). Limpopo clinic without immunization meds for months. Health-e news. URL: https://health-e.org/2013/02/07/limpopo-clinicwithout-immunization-meds-for-months/. Accessed May 2020.

49. Health-e News. (2007). Poor health system hits the poor hard. Health-e news. URL: https://health-e.org/2007/10/14/poor-health-system-hits-thepoor-hard/. Accessed May 2020.

50. Department of Water Affairs Forestry (DWAF). (1996) South African water quality guidelines, 2nd edition, Vol 2: Domestic use, The Government Printer, Pretoria, South Africa. Available from www.dwaf.gov.za/IWQS/wq guide/domestic.pdf. Accessed May 2020.

51. WHO (2017). Guidelines for drinking water quality, fourth edition incorporating the first addendum. URL: http://apps.who.int/iris/bitstream/handle/1 0665/254637/9789241549950-eng.pdf?sequence=1. Accessed May 2020.

52. Bain $\mathrm{R}$, Cronk R, Wright J, Yang H, Slaymaker T, Bartram J. Fecal contamination of drinking water in low- and middle-income countries: a systematic review and meta-analysis. PLoS Med. 2014;11(5):e1001644.

53. Bain RES, Wright JA, Christenson E, Bartram JK. Rural: urban inequalities in post 2015 targets and indicators for drinking water. Sci Total Environ. 2014; 490:509-13. 
54. Guo AZ, Bartram JK. Predictors of water quality in rural health care facilities in 14 low-and middle-income countries. J Clean Prod. 2019;237:117836.

55. Du Preez M. The quality of potable water in rural health care facilities. Water Research Commission report KV 188/07. Pretoria: WRC publishing; 2007.

56. Traore AN, Mulaudzi K, Chari GJ, Foord SH, Mudau LS, Barnard TG, Potgieter N. The impact of human activities on microbial quality of rivers in the Vhembe District, South Africa. Int J Environ Res Public Health. 2016;13(8):817.

57. Obi CL, Potgieter $N$, Bessong PO, Matsaung G. Assessment of the microbial quality of river water sources in rural Venda communities in South Africa. Water SA. 2002;28:287-92.

58. Potgieter N, Mudau LS, Maluleke FRS. Microbiological quality of groundwater sources used by rural communities in Limpopo Province, South Africa. Water Sci Technol. 2006;54(11-12):371-7.

59. Potgieter N, Karambwe S, Mudau LS, Barnard TG, Traore A. Human enteric pathogens in eight Rivers used as rural household drinking water sources in the northern region of South Africa. Int J Environ Res Public Health. 2020; 17(6). https://doi.org/10.3390/ijerph17062079.

60. Obi CL, Green E, Bessong PO, De Villiers B, Hoosen AA, Igumbor EO, Potgieter N. Gene encoding virulence markers among Escherichia coli isolates from diarrhoeic stool samples and river sources in rural Venda communities of South Africa. Water SA. 2004;30(1):37-42.

61. Obi CL, Potgieter N, Bessong PO, Igumbor EO, Green E. Prevalence of pathogenic bacteria and rotaviruses in stools of patients presenting with diarrhoea from rural communities in Venda, South Africa. S Afr J Sci. 2003; 99(11-12):589-92.

62. Samie A, Guerrant RL, Barrett L, Bessong PO, Igumbor EO, Obi CL. Prevalence of intestinal parasitic and bacterial pathogens in diarrhoeal and non-diarroeal human stools from Vhembe district, South Africa. J Health Popul Nutr. 2009;27(6):739.

63. Ledwaba SE, Kabue JP, Barnard TG, Traore AN, Potgieter N. Enteric pathogen co-infections in the paediatric population from rural communities in the Vhembe District, South Africa. South Afr J Child Health. 2018;12(4):170-4

64. Kong $H$, Xong $X$, Li X. Current perspectives in pathogenesis and antimicrobial resistance of entero-aggregative Escherichia coli. Microb Pathog. 2015;85:44-9.

65. Dutta S, Pazhani GP, Nataro JP, Ramamurthy T. Heterogenic virulence in a diarrhoeagenic Escherichia coli: evidence for EPEC expressing heat-labile toxin of ETEC. Int J Med Microbiol. 2014;305:47-54.

66. Nataro JP, Kaper JB. Diarrheagenic Escherichia coli. Clin Microbiol Rev. 1998; 11:142-201.

67. Dutta S, Guin S, Ghosh S, Pazhani GP, Rajendran K, Bhattacharya MK, Takeda $Y$, Nair GB, Ramamurthy T. Trends in the prevalence of diarrheagenic Escherichia coli among hospitalized diarrheal patients in Kolkata, India. PLoS One. 2013;8(2):e56068.

68. Semmler T, Eichhorn I, Bethe A, Bauerfeind R, Pickard D, Kingsley RA Dougan G, Wieler LH. Genome sequence of porcine Escherichia coli strains IMT8079, an atypical enteropathogenic E. coli isolated from a piglet with diarrhea. Genome Announcements. 2013;1(4):e00573.

69. Aquagenx LLC. (2013). Compartmental bag test: instructions for use. www. aquagenc.com. Accessed May 2020.

70. McGinnis S, Marini D, Amatya P, Murphy HM. Bacterial contamination on latrine surfaces in community and household latrines in Kathmandu, Nepal. Int J Environ Res Public Health. 2019;16:257. https://doi.org/10.3390/ ijerph16020257.

71. Allegranzi B, Pittet D. Role of hand hygiene in health care associated infection prevention. J Hosp Infect. 2009;73:305-15.

72. WHO. WHO guidelines on hand hygiene in health care: first global patient safety challenge, clean care is safer care. Geneva, Switzerland: WHO Press; 2009.

73. Hernandez JE, Mejia CR, Cazali IL, Arathoon EG. Nosocomial infection due to vibrio cholerae in two referral hospitals in Guatamala. Infect Control Hosp Epidemiol. 1996;17:371-2.

74. Swaddiwudhipong W, Peanumlom P. A case of nosocomial cholera during community outbreak in a Thai-Myamar border area. J Med Assoc Thail. 2010;93:1112-4.

75. Oloniya FC, Ogola JS, Tshitangano TG. Efficiency of health care risk waste management in rural health care facilities of South Africa: an assessment of selected facilities in Vhembe District, Limpopo Porvince. Int J Environ Res Public Health. 2019;16. https://doi.org/10.3390/ijerph16122199.

\section{Publisher's Note}

Springer Nature remains neutral with regard to jurisdictional claims in published maps and institutional affiliations.
Ready to submit your research? Choose BMC and benefit from:

- fast, convenient online submission

- thorough peer review by experienced researchers in your field

- rapid publication on acceptance

- support for research data, including large and complex data types

- gold Open Access which fosters wider collaboration and increased citations

- maximum visibility for your research: over $100 \mathrm{M}$ website views per year

At BMC, research is always in progress.

Learn more biomedcentral.com/submissions 